\title{
A Review on the Use of Essential Oil-Based Nanoformulations in Control of Mosquitoes
}

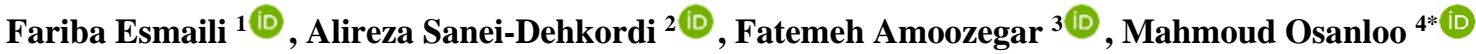 \\ 1 Department of Medical Nanotechnology, School of Advanced Technologies in Medicine, Tehran University of Medical \\ Sciences, Tehran, Iran; fesmaeili2010@gmail.com (F.E.); \\ 2 Department of Medical Entomology, School of Health, Hormozgan University of Medical Sciences, Hormozgan, Iran; \\ alireza.sanee@gmail.com (A.S.D); \\ 3 Student Research Committee, Fasa University of Medical Sciences, Fasa, Iran; amoozegar.fateme@gmail.com (F.A.); \\ 4 Department of Medical Nanotechnology, School of Advanced Technologies in Medicine, Fasa, Iran; \\ m.osanloo@fums.ac.ir (M.O.); \\ * Correspondence: m.osanloo@fums.ac.ir; osanloo_mahmood@yahoo.com;
}

Received: 16.12.2020; Revised: 20.01.2021; Accepted: 23.01.2021; Published: 30.01.2021

\begin{abstract}
It is estimated that one million deaths per year are caused by mosquito-borne diseases worldwide. While preventing such diseases is possible and, of course, more manageable than attended to treat patients. Prevention of these diseases is based on improving the environment (e.g., decreased stagnant water) and controlling mosquitoes in immature and adult forms. Resistances among mosquitoes, environmental pollution, and adverse effects on non-target species, such as humans, are some of the major disadvantages of using chemical insecticides. Essential oils (EO)s with a wide range of activities on mosquitoes, including ovicide effect, larvicide effect, pupicide effect, adulticide effects, and repellent effect, are proper alternatives for synthetic ones. However, their practical usage is questioned due to their volatility and lower efficiency than synthetic samples. In recent years, researchers have attended to overcome these challenges by formulating EOs into nanoformulations. In this study, existing reports on exploiting EO-based nanoformulations in mosquito control have been categorized as larvicides, repellents, and adulticides. Moreover, by discussing the reported results, the appropriate nanoformulations for each purpose have been suggested; polymeric nanoparticles are more suitable for larvicides, lipid nanocarriers are more suitable for repellents nanoemulsions are more suitable for adulticide.
\end{abstract}

Keywords: essential oil; nanoemulsion; polymeric nanoparticles; lipidic nanocarriers.

(C) 2021 by the authors. This article is an open-access article distributed under the terms and conditions of the Creative Commons Attribution (CC BY) license (https://creativecommons.org/licenses/by/4.0/).

\section{Introduction}

Mosquitoes are the most important arthropods in public health [1,2]. They could transmit many diseases, such as malaria, dengue, yellow fever, chikungunya, encephalitis, and filariasis [3,4]. Malaria is the most important mosquito-borne disease; 228 million malaria cases and 405,000 deaths were reported worldwide just in 2018 [5,6]. Besides, the global incidence of Aedes-borne disease has grown dramatically in recent decades [7,8]. Nearly half the world's population is at risk of infection by dengue; 400 million infections occur per year, of which approximately one-quarter of these patients manifest clinically [9].

Management of mosquitoes is a serious concern in developing countries facing vectorborne disease outbreaks [10,11]. Synthetic (chemical) insecticides are commonly used compounds for the control of both immature (egg, larva, and pupa) and mature stages of 
mosquitoes [12,13]. Adverse effects on the environment (contaminating soil, water, and air), side effects on non-target populations (especially humans), and the development of resistance has increased considerably in recent years [14,15]. Furthermore, synthetic repellents' application to exposed skin to protect from mosquito bites is a common approach for reducing the transmission of mosquito-borne diseases and irritating bites [16]. However, there are concerns about their toxicity and safety $[17,18]$. These limitations have necessitated researchers to develop new compounds to combating mosquitos and preventing mosquito bites.

Essential oils (EO)s are naturally oily liquids that commonly extracted through hydro distillation from different parts (bark, stem, flower, and rhizome) of aromatic plants using the Clevenger type apparatus $[19,20]$. They have possessed a wide range of biological activities such as antibacterial effect [21,22], leishmanicidal effects [23,24], larvicidal effect [25,26], and repellent effects [27,28]. Recently, EO-based insecticides were introduced as alternatives to synthetic ones to control mosquitos because of their selective action on target and minimal side effects on non-target organisms and their high degradation in the environment $[29,30]$. The literature includes many studies about using EOs against mosquitoes [31,32]. However, applications of EOs as insecticide and repellent are limited because some of their ingredients are volatile.

Nanotechnology is targeted manipulations of materials in the nanoscale (especially 1 $200 \mathrm{~nm}$ ) for obtaining size-dependent features or functions [33,34]. The novel approach to stabilize EOs and improve their stability is formulating them into nanoformulations [35,36]. It has been accepted that by decreasing the droplets' size and increasing the surface-to-volume ratio, the solubility of EOs is improved, which ultimately leads to enhanced efficacy $[37,38]$. Formulating EOs into nanoformulation has recently been considered a promising approach for improving the stability and efficacy of EOs $[39,40]$.

\section{Review Methodology}

Almost all reports (till 07.31.2020) on using only EO-based nanoformulations to control mosquitoes have been reviewed. For this purpose, three different channels, including the search engine (Google Scholar), indexed databases of scientific publications (PubMed), and also academic networks (Research Gate) were searched to find any original or review articles, commentaries, and reports related to this subject. Collected documents have been categorized as their reported approach to mosquito control, including larvicide, repellent, and adulticide. No research has yet been reported on the ovicidal and pupicidal effect of EO-based nanoformulations.

Due to the lipophilic nature of EOs, three types of formulations have been widely used for the preparation of EO-based nanoformulations; nanoemulsions, lipid-based nanocarriers (liposomes, solid lipid nanoparticles (SLN), and nanostructured lipid carriers (NLC)), and polymeric nanoparticles. For a better discussion, a brief about the mentioned nanoformulations has been first given.

\subsection{Nanoemulsions.}

The mixture of two phases of water and oil is called emulsion; if droplet size is at the nanoscale, they called nanoemulsion [41]. Emulsions are classified as two basic categories of oil-in-water (O/W) and water-in-oil (W/O); in the former, oil as droplets are dispersed in water, but in the latter, vice versa (see Figure $1 \mathrm{~A}$ and $1 \mathrm{~B}$ ). In both, surfactants or surface tension 
reducing agents are used to mix the two phases. In particular, O/W nanoemulsions are much more frequently used because most of the drugs and all EOs are lipophilic and should be solubilized in blood flow or water $(41,42)$.

Nanoemulsions generally are prepared using high- and low-energy techniques. Ultrasonic-, a high-pressure homogenizer-, and microfluidizer-assisted fabrications belong to high energy methods. Low-energy techniques include phase inversion temperature, phase inversion composition, and solvent diffusion or spontaneous emulsification [42,43]. Given that some of the components of EOs are volatile, spontaneous emulsification is preferred over other approaches to prepare EO-based nanoemulsions. In this technique, nanoemulsions are prepared based on optimizing oil, water, and surfactant $[35,44]$. Thus, the prepared nanoemulsions in such a manner are not affected by physical and chemical stress, such as temperature and $\mathrm{pH}$ $[45,46]$.

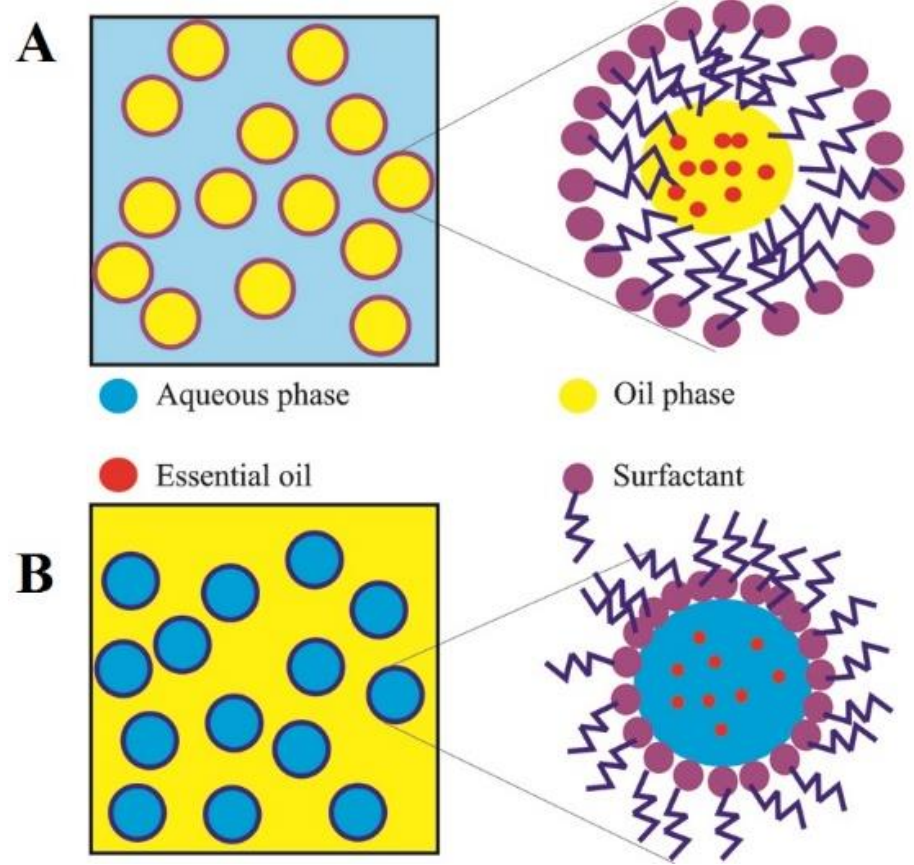

Figure 1. A: oil in water nanoemulsion, B: water in oil nanoemulsion.

\subsection{Lipid-based nanocarriers.}

Lipid-based carriers are suitable candidates for delivering various water-insoluble drugs and EOs due to the hydrophobic nature. They could increase drug molecules' solubility and stability, which led to improved pharmacokinetics' performance [47]. Moreover, compared to polymeric nanoparticles, their biocompatibility, and capacity to encapsulate highly lipophilic active substances are higher [48]. The following paragraphs describe some of the common lipid-based nanoformulations.

Liposomes composed of phospholipids and cholesterol; they formed a bilayered spherical structure by hydration in an aqueous medium (see Figure 2A). The presence of cholesterol in the liposome structure increases bilayers' stability and decreases cargos leakage [49]. Interestingly, both hydrophilic/phobic drugs could be loaded into liposomes; the phospholipid bilayer is a suitable space for hydrophobic drugs and the aqueous cavity for hydrophilic ones. Therefore, liposomes are commonly used in the pharmaceutical, cosmetic, and food industries [49]. Liposomes could increase the stability, solubility, and bioavailability of the drugs. Moreover, by encapsulating EOs into liposomes, they are preserved from oxidation and evaporation [50]. 
Depend on preparation methods, different liposomes from a few nanometers to micrometers have been reported. The common approaches are thin-film hydration, freezedrying, reverse evaporation, and ethanol injection [51]. Among these approaches, thin-film hydration is mostly employed in the preparation of liposomes. In this method, lipid components containing a drug are dissolved in an organic solvent. The solvent is evaporated using rotary evaporation, and the lipid film is rehydrated in an aqueous solvent. Some techniques, including homogenization, sonication, freeze-thawing, and membrane extrusion, are used to control liposomes' size and size distribution [52].

Solid Lipid Nanoparticles (SLN) are biodegradable and biocompatible nanoformulation. They are prepared by dispersing physiological lipids and surfactants (for stabilization) in an aqueous phase in a size of 50 to $200 \mathrm{~nm}$ (see Figure 2B) [51,53]. In SLNs, the drug is dissolved in lipids with high melting points $\left(>40^{\circ} \mathrm{C}\right)$ [54]. Since SLNs maintain they are solid-state at body temperature, they are attractive as long-acting or controlled-release formulations [47]. From the literature, SLNs commonly have been used for the delivery of different drugs, e.g., budesonide-loaded SLN for management of asthma [55], curcumin loaded SLNs to the improvement of oral bioavailability [56], SLN loaded kiteplatin for treatment of glioblastoma multiform [57]. Besides, SLNs have the potential to encapsulate EOs to control release. For example, Zhao et al. have prepared EO-loaded SLNs through a high-shearing homogenization technique for sustained inhalation [58].

Nanostructured Lipid Carriers (NLC) are another class of lipid nanoparticles that both liquid lipids solid lipids are used in their structure (see Figure 2C). Thus, their melting point is lower than SLNs; however, they preserved solid-state at room temperature. NLC is stabilized in an aqueous phase using a or combination of surfactants [59]. Many techniques for the preparation of NLC have been reported, e.g., displacement of solvents, micro emulsification, and high-pressure homogenizer. The high-pressure homogenizer is favorable, as no solvents are required in the preparation. Briefly, the mixture of drug-containing lipids is melted (about $10{ }^{\circ} \mathrm{C}$ above the melting temperature). The hot surfactant solution is then added and mixed using a high-pressure homogenizer [60].

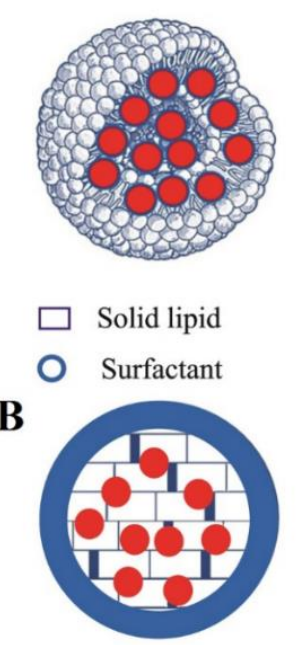

A

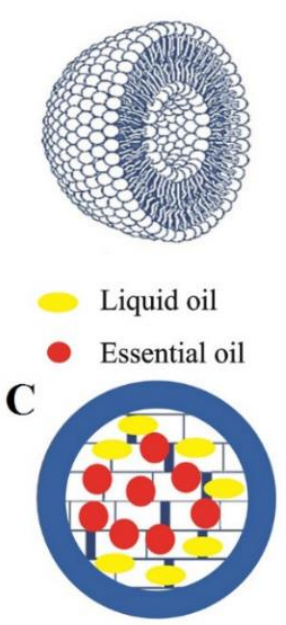

Figure 2. Lipid-based nanocarriers; A: liposome, B: solid lipid nanoparticles; C: nanostructured lipid carriers.

\subsection{Polymeric nanoparticles.}

Polymeric nanoparticles could be described as colloidal polymeric particles in a size range of 1-200 nm [61]. Polymeric nanoparticles could be biodegradable or nonbiodegradable; however, the degradation rate and drug release rate could be modified using a 
different mixture of polymers [37]. Some of the advantages of polymeric nanoparticles as drug/EOs carriers include proper control of the size, prolonged elimination, increased therapeutic effectiveness, simple preparation procedure, low toxicity, and drug preservation $[62,63]$. As demonstrated in Figure $3 \mathrm{~A}$ and B, cargoes could be incorporated in the matrix of polymeric nanoparticles (called nanospheres) or loaded in the core (called nanocapsules) $[64,65]$.

Polymeric nanoparticles could be prepared using natural polymers such as chitosan, hyaluronic acid, and albumin, or from semi/synthetic polymers such as poly (lactide-coglycolide) (PLGA), polyglycolic acid (PGA), polyacrylic acid (PAA), polylactic acid (PLA), and cellulose derivatives including carboxymethyl cellulose (CMC) and Hydroxypropyl methylcellulose (HPMC) [66,67]. Furthermore, nanoparticles are prepared using various methods, such as nanoprecipitation, solvent evaporation, ionotropic gelation, electrospray, salting out, and supercritical fluid technology $[68,69]$.
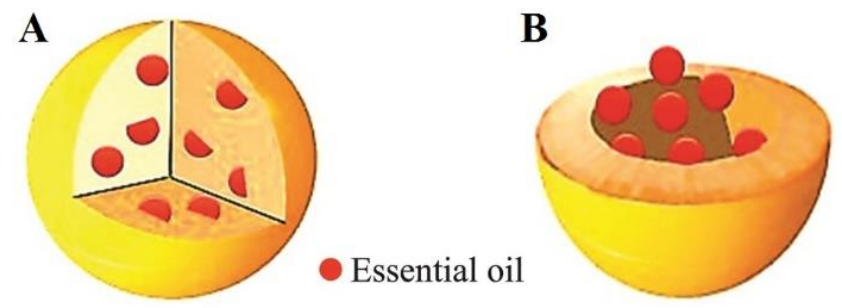

Figure 3. Polymeric nanocarriers: A: polymeric nanosphere, B: polymeric nanocapsule.

\section{The Use of EO-based Nanoformulations for Control of Mosquitoes}

Collected documents have been analyzed, and the use of EO-base nanoformulations are categorized as larvicide, repellent, and adulticide.

\subsection{EO-based nanoformulations as larvicides.}

Twenty EO-based nanoformulations as larvicides are listed in Table 1. Seventeen of them are nanoemulsions, and three others are chitosan nanostructures, including nanoparticles and nanobeads. Reasons for excessive utilization of nanoemulsions compared to other nanoformulations are easier access to the constituents and more straightforward preparation methods.

In the five first reports, only the larvicidal activity of nanoformulations was reported; therefore, the effect of nanoformulation on the efficiency of EOs could not be evaluated [70-73]. In such reports, the efficiency of nanoformulations should be compared with nonformulated EOs.

According to the other fifteen reports, the achievement of nanoformulation of EOs as larvicide are summarized into four classifications. In two reports, nanoemulsions' effects were significantly improved than non-formulated EOs at an examined concentration [74,75]. In another study, the perfect larvicidal effect (100\% mortality) was achieved at 4 hours instead of 24 hours, related to non-formulated EO [76]. In 10 reports, reported lethal concentration 50 (LC50) of nanoemulsions were significantly better than those of non-formulated EOs. In the two latest reports, continuity of larvicidal activity was investigated. Tarragon EO was encapsulated in chitosan nanoparticles at two different concentrations. The larvicidal effect of tarragon EO at concentrations of 1.6 and $6 \%$ was continued 2 and 4 days, while these times in nanoformulated forms were significantly improved, i.e., 4 and 9 days $[77,78]$. 
The physical stability of nanoemulsion is generally high; however, when they diluted during larvicidal tests (100-200 times), their stability is great decreases. Instability ultimately leads to short-term durability of the larvicidal effects [74,75]. Thus, the long-lasting larvicidal activity for nanoemulsions has not been reported; as described above, only the efficiency of EOs was improved.

The stability and loading capacity of lipidic nanocarriers for EOs is good. Besides, their spontaneous aggregation in the aqueous phase has been solved by exploiting different stabilization methods such as steric and electrostatic manners [79,80]. However, lipidic nanocarriers' preparation for spraying the environment on a large scale is not economically viable. In this regard, polymer nanoparticles (such as chitosan) with high stability and lower cost are preferred to prepare larvicides [77,78].

Furthermore, numerous articles have been published on the larvicidal properties of plant-synthesized silver nanoparticles. In such a manner, herbal extracts are used as reducing agents for the synthesis of silver nanoparticles from their salts, such as $\mathrm{AgNO}_{3}$ or $\mathrm{AgCl}$ [81]. This method does not require toxic reducing agents $[82,83]$. Nevertheless, an important point has been overlooked in these reports; silver nanoparticles easily interact with chemical functional groups. Thus, silver nanoparticles' final properties are strongly dependent on reducing agent, i.e., herbal extracts $[84,85]$. For instance, reported LC $_{50}$ of plant-synthesized silver nanoparticles was varied from 2 to $12470 \mathrm{ppm}$ against An. stephensi [86,87]. In our previous study, chemically synthesized nanoparticles with a particle size of $30 \mathrm{~nm}$ showed only a $20 \%$ larvicidal effect at $100 \mathrm{ppm}$ [88]. In general, silver nanoparticles are not good candidates for larvicidal purposes on a large scale due to their high price, environmental pollution, and varied efficacy.

Table 1. EO-based nanoformulations as larvicides.

\begin{tabular}{|c|c|c|c|c|}
\hline References & EO names & $\begin{array}{l}\text { Nanoformulation } \\
\text { (size) }\end{array}$ & Target larvae & Achievement \\
\hline [70] & $\begin{array}{l}\text { Ocimum } \\
\text { basilicum }\end{array}$ & $\begin{array}{l}\text { nanoemulsion } \\
(28 \mathrm{~nm})\end{array}$ & $\begin{array}{l}\text { Cx. } \\
\text { quinquefasciatus }\end{array}$ & $\begin{array}{l}\text { Larvicidal effect of nanoemulsion at } 50 \\
\mu \mathrm{g} / \mathrm{mL}: 100 \% \\
\text { EO no reported }\end{array}$ \\
\hline [71] & $\begin{array}{l}\text { Azadirachta } \\
\text { indica }\end{array}$ & $\begin{array}{l}\text { nanoemulsion } \\
(31.03)\end{array}$ & $\begin{array}{l}\text { Cx. } \\
\text { quinquefasciatus }\end{array}$ & $\begin{array}{l}\mathrm{L} \mathrm{C}_{50} \text { of nanoemulsion reported at } 11.75 \\
\mu \mathrm{g} / \mathrm{mL} \\
\text { EO no reported }\end{array}$ \\
\hline [72] & $\begin{array}{l}\text { Pterodon } \\
\text { emarginatus }\end{array}$ & $\begin{array}{l}\text { nanoemulsion } \\
(125 \mathrm{~nm})\end{array}$ & Ae. aegypti & $\begin{array}{l}\text { Larvicidal effect of nanoemulsion at } 250 \\
\mu \mathrm{g} / \mathrm{mL}: 100 \% \\
\text { EO no reported }\end{array}$ \\
\hline [73] & Lippia alba & $\begin{array}{l}\text { nanoemulsion } \\
(117.0 \mathrm{~nm})\end{array}$ & Ae. aegypti & $\begin{array}{l}\mathrm{LC}_{50} \text { of nanoemulsion reported at } 31.02 \\
\mu \mathrm{g} / \mathrm{mL} \\
\text { EO no reported }\end{array}$ \\
\hline [73] & Lippia alba & $\begin{array}{l}\text { nanoemulsion } \\
(117.0 \mathrm{~nm})\end{array}$ & $\begin{array}{l}\text { Cx. } \\
\text { quinquefasciatus }\end{array}$ & $\begin{array}{l}\mathrm{LC}_{50} \text { of nanoemulsion reported at } 38.22 \\
\mu \mathrm{g} / \mathrm{mL} \\
\text { EO no reported }\end{array}$ \\
\hline [74] & $\begin{array}{l}\text { Anethum } \\
\text { graveolens }\end{array}$ & $\begin{array}{l}\text { nanoemulsion } \\
(10.7 \mathrm{~nm})\end{array}$ & An. stephensi & $\begin{array}{l}\text { Larvicidal effect of the EO increased from } \\
73.4 \text { to } 88.1 \% \text { at } 60 \mu \mathrm{g} / \mathrm{mL}\end{array}$ \\
\hline [75] & $\begin{array}{l}\text { Artemisia } \\
\text { dracunculus }\end{array}$ & $\begin{array}{l}\text { nanoemulsion } \\
(14.5)\end{array}$ & An. stephensi & $\begin{array}{l}\text { Larvicidal effect of the EO increased from } \\
83.4 \text { to } 92.71 \% \text { at } 18 \mu \mathrm{g} / \mathrm{mL}\end{array}$ \\
\hline [76] & $\begin{array}{l}\text { Eucalyptus } \\
\text { globulus }\end{array}$ & $\begin{array}{l}\text { nanoemulsion } \\
(9.4 \mathrm{~nm})\end{array}$ & $\begin{array}{l}\text { Cx. } \\
\text { quinquefasciatus }\end{array}$ & $\begin{array}{l}\text { Larvicidal effect of EO at } 250 \mu \mathrm{g} / \mathrm{mL} \text { : } \\
100 \% \text { in } 24 \text { h exposure } \\
\text { For nanoemulsion: } 4 \text { h exposure }\end{array}$ \\
\hline [89] & Citrus sinensis & $\begin{array}{l}\text { nanoemulsion } \\
(78.8 \mathrm{~nm})\end{array}$ & Cx. pipiens & $\begin{array}{l}\mathrm{LC}_{50} \text { of the EO decreased from } 86.3 \text { to } \\
27.4 \mu \mathrm{g} / \mathrm{mL}\end{array}$ \\
\hline [90] & $\begin{array}{l}\text { Mentha } \\
\text { piperita }\end{array}$ & $\begin{array}{l}\text { nanoemulsion } \\
(34 \mathrm{~nm})\end{array}$ & Cx. pipiens & $\begin{array}{l}\text { LC } 50 \text { of the EO decreased from } 88.90 \text { to } \\
31.24 \mu \mathrm{g} / \mathrm{mL}\end{array}$ \\
\hline [91] & Croton linearis & $\begin{array}{l}\text { nanoemulsion } \\
(163 \mathrm{~nm})\end{array}$ & Ae. aegypti & $\begin{array}{l}\mathrm{LC}_{50} \text { of the EO decreased from } 64.24 \text { to } \\
17.86 \mu \mathrm{g} / \mathrm{mL}\end{array}$ \\
\hline [92] & $\begin{array}{l}\text { Anacardium } \\
\text { occidentale }\end{array}$ & $\begin{array}{l}\text { nanoemulsion } \\
(52 \mathrm{~nm})\end{array}$ & An. culicifacies & $\begin{array}{l}\text { LC } 50 \text { of the EO decreased from } 18.1 \text { to } 1.4 \\
\mu \mathrm{g} / \mathrm{mL}\end{array}$ \\
\hline
\end{tabular}




\begin{tabular}{|c|c|c|c|c|}
\hline References & EO names & $\begin{array}{l}\text { Nanoformulation } \\
\text { (size) }\end{array}$ & Target larvae & Achievement \\
\hline [93] & $\begin{array}{l}\text { Siparuna } \\
\text { guianensis }\end{array}$ & $\begin{array}{l}\text { nanoemulsion } \\
(176 \mathrm{~nm})\end{array}$ & Aedes aegypti & $\begin{array}{l}\text { LC } 50 \text { of the EO decreased from } 86.52 \text { to } \\
24.75 \mu \mathrm{g} / \mathrm{mL}\end{array}$ \\
\hline [94] & $\begin{array}{l}\text { Ricinus } \\
\text { communis }\end{array}$ & $\begin{array}{l}\text { nanoemulsion } \\
(114 \mathrm{~nm})\end{array}$ & An. culicifacies & $\begin{array}{l}\mathrm{LC}_{50} \text { of the EO decreased from } 52.3 \text { to } 3.4 \\
\mu \mathrm{g} / \mathrm{mL}\end{array}$ \\
\hline [95] & $\begin{array}{l}\text { Ficus } \\
\text { glomerata }\end{array}$ & $\begin{array}{l}\text { nanocrystal emulsion } \\
(104 \mathrm{~nm})\end{array}$ & Ae. aegypti & $\begin{array}{l}\text { LC } 50 \text { of the EO decreased from } 60 \text { to } 20 \\
\mu \mathrm{g} / \mathrm{mL}\end{array}$ \\
\hline [95] & $\begin{array}{l}\text { Ficus } \\
\text { glomerata }\end{array}$ & $\begin{array}{l}\text { nanocrystal emulsion } \\
(104 \mathrm{~nm})\end{array}$ & $\begin{array}{l}\text { Cx. } \\
\text { quinquefasciatus }\end{array}$ & $\begin{array}{l}\mathrm{LC}_{50} \text { of the EO decreased from } 48 \text { to } 22 \\
\mu \mathrm{g} / \mathrm{mL}\end{array}$ \\
\hline [95] & $\begin{array}{l}\text { Ficus } \\
\text { glomerata }\end{array}$ & $\begin{array}{l}\text { nanocrystal emulsion } \\
(104 \mathrm{~nm})\end{array}$ & An. stephensi & $\begin{array}{l}\text { LC } 50 \text { of the EO decreased from } 60 \text { to } 17 \\
\mu \mathrm{g} / \mathrm{mL}\end{array}$ \\
\hline [96] & $\begin{array}{l}\text { Eucalyptus } \\
\text { globulus }\end{array}$ & $\begin{array}{l}\text { chitosan beads } \\
(200 \mathrm{~nm})\end{array}$ & Cx. pipiens & $\begin{array}{l}\text { LC } 50 \text { of the EO decreased from } 20.301 \text { to } \\
0.419 \mu \mathrm{g} / \mathrm{mL}\end{array}$ \\
\hline [77] & $\begin{array}{l}\text { Artemisia } \\
\text { dracunculus }\end{array}$ & $\begin{array}{l}\text { chitosan nanoparticles } \\
\text { containing } 1.6 \% \text { EO } \\
(168 \mathrm{~nm})\end{array}$ & An. stephensi & $\begin{array}{l}\text { Continuity of larvicidal effect of the EO } \\
\text { increased from } 2 \text { to } 4 \text { days }\end{array}$ \\
\hline [78] & $\begin{array}{l}\text { Artemisia } \\
\text { dracunculus }\end{array}$ & $\begin{array}{l}\text { chitosan nanoparticles } \\
\text { containing 6\% EO } \\
(222 \mathrm{~nm})\end{array}$ & An. stephensi & $\begin{array}{l}\text { Continuity of larvicidal effect of the EO } \\
\text { increased from } 4 \text { to } 9 \text { days }\end{array}$ \\
\hline
\end{tabular}

\subsection{EO-based nanoformulations as repellents.}

One of the most synthetic insect repellents (without insecticidal effect) is DEET (N, Ndiethyl-meta-toluamide), which is used as a gold standard in many repellency tests [97]. However, DEET's application has been questioned due to side effects such as allergy, dermatitis, cardiovascular and neurological disorders, and damage to the synthetic fabric and plastic $[98,99]$. So recently, much attention has been paid to the development of green repellents. Details of EO-based nanoemulsions as repellent are given in Table 2. Noted, microencapsulated lemongrass EO as repellent was also reported in the literature; however, that was related to preparing texture (polyester) with repellent activity [100].

A control group (chemical repellent or non-formulated EO) has not been reported in the two first reports in Table 2, so it is impossible to determine the advantages of using the nanoformulations. However, reported protection times are acceptable [101,102]; according to the Environmental Protection Agency (EPA), the minimum repellent time to obtain registration is 2 hours [103].

In the other reports, EO-based nanoformulations' efficiencies were comparable with synthetic repellents. For instance, protection times of nanoemulsion of Eucalyptus globulus $(15 \%)$ and DEET 15\% against a mixture of mosquitoes were reported at 170 and $211 \mathrm{~min}$ [104]. Besides, nanoemulsion of EOs of Mentha piperita (50\%) and Eucalyptus globulus (50\%) was prepared with protection times of 257 and 351 min against An. stephensi; this time for DEET $25 \%$ was 370 min [105].

Furthermore, the protection time of nanocrystal emulsion of Ficus glomerata was comparable with an Odomos (synthetic repellent) against three mosquitoes [95]. For the preparation of this formulation (FON), a nanoemulsion of neem oil (NON) was first prepared. Then, ethanol extract of the plant was added for crystallization of emulsion. The repellent effects of FON, NON, and Odomos were reported as follows; Ae. aegypti: 234, 192, and 223 min, An. stephensi: 238, 198, and $230 \mathrm{~min}$, and Cx. Quinquefasciatus: 233, 193, and $229 \mathrm{~min}$ [95].

The stratum corneum cells (corneocytes) are dense, functionally dead, anucleated, and filled with keratin. Also, some lipids are forming several bilayers surrounded the corneocytes. Intercellular fat consists of a mixture of ceramides, cholesterol, and fatty acids [106]. Reviewing the literature, a substance with moderate lipophilicity could transit through the 
stratum corneum, but the more hydrophilic substance is inhibited in the epidermis and dermis. However, when skin hydrated, the stratum corneum considerably swells and shows increased permeability $[79,97]$.

Given that nanoemulsions contained a high amount of water; therefore, part of the formulation penetrates the skin after hydration. The other part evaporates. It is also topically usage of nanoemulsions are challenges due to low viscosity. Therefore, contrary to existing reports, nanoemulsions are not a suitable formulation as repellents.

Furthermore, high lipophilic materials accumulate in the skin's uppermost layers, where their action as sunscreen or repellent should occur [79]. Incorporating sunscreen (or repellent) in the lipidic nanocarriers appeared to bind to keratin for an extended period and serve as a reservoir for elongation of their activity [80]. Therefore, lipidic nanocarriers with higher viscosity (easier topical usage) are better candidates for preparing EO-based nanoformulations as repellents.

Table 2. EO-based nanoformulations as repellents.

\begin{tabular}{|c|c|c|c|c|}
\hline References & EO names & $\begin{array}{l}\text { Nanoformulation } \\
\text { (size) }\end{array}$ & Target mosquitoes & Protection time \\
\hline [101] & Cymbopogon nardus & $\begin{array}{l}\text { nanoemulsion } \\
(135 \mathrm{~nm})\end{array}$ & Ae. aegypti & $\begin{array}{l}168 \text { min } \\
\text { No control }\end{array}$ \\
\hline [102] & $\begin{array}{l}\begin{array}{l}\text { citronella } \\
\text { hairy basil } \\
\text { vetiver (5\%) }\end{array} \\
\text { ver) }\end{array}$ & $\begin{array}{l}\text { nanoemulsion } \\
(153.7)\end{array}$ & Ae. aegypti & $\begin{array}{l}282 \\
\text { No control }\end{array}$ \\
\hline [104] & Eucalyptus globulus & $\begin{array}{l}\text { nanoemulsion } \\
\mathrm{nm})\end{array}$ & $\begin{array}{l}\text { Cx. pipiens } \quad(62 \%), \\
\text { Ochlerotatus caspius } \\
(22 \%), \\
\begin{array}{l}\text { Cx. pusillus }(10 \%) \quad C x . \\
\text { tritaeniorhynchus }(6 \%) .\end{array}\end{array}$ & $\begin{array}{l}170 \mathrm{~min} \\
\text { DEET: } 211 \mathrm{~min}\end{array}$ \\
\hline [105] & Mentha piperita & $\begin{array}{l}\text { nanoemulsion }(11.32 \\
\mathrm{nm})\end{array}$ & An. stephensi & $\begin{array}{l}257 \mathrm{~min} \\
\text { DEET: } 370 \mathrm{~min}\end{array}$ \\
\hline [105] & Eucalyptus globulus & $\begin{array}{l}\text { nanoemulsion } \\
(103.90 \mathrm{~nm})\end{array}$ & An. stephensi & $\begin{array}{l}351 \mathrm{~min} \\
\text { DEET: } 370 \mathrm{~min}\end{array}$ \\
\hline [95] & Ficus glomerata & $\begin{array}{l}\text { nanocrystal emulsion } \\
(104 \mathrm{~nm})\end{array}$ & Cx. quinquefasciatus & $\begin{array}{l}233 \mathrm{~min} \\
\text { Odomos: } 229 \mathrm{~min}\end{array}$ \\
\hline [95] & Ficus glomerata & $\begin{array}{l}\text { nanocrystal emulsion } \\
(104 \mathrm{~nm})\end{array}$ & An. stephensi & $\begin{array}{l}238 \min \\
\text { Odomos:230 min }\end{array}$ \\
\hline [95] & Ficus glomerata & $\begin{array}{l}\text { nanocrystal emulsion } \\
(104 \mathrm{~nm})\end{array}$ & Ae. aegypti & $\begin{array}{l}234 \min \\
\text { Odomos:223 min }\end{array}$ \\
\hline
\end{tabular}

\subsection{EO-based nanoformulations as adulticides.}

Only one document has been found on the adulticide effect of EO-based nanoformulations. Nanoemulsion of Ocimum sanctum EO was prepared; however, its particle size was not reported. The knockdown effect (KD50) of the nanoformulation after one-hour exposure with Ae. aegypti and Cx. quinquefasciatus were reported as 7.01 and $4.05 \mathrm{mg} / \mathrm{cm}^{2}$. Its lethal dose fifty $\left(\mathrm{LD}_{50}\right)$ after 24 hours of exposure were also reported at 28.60 and 20.09 $\mathrm{mg} / \mathrm{cm}^{2}$ [107].

However, not many studies have been reported in this area (EO-based nanoformulations as adulticides). In residual spraying, the toxin's effect should not remain on the wall, so it seems that nanoemulsions are proper candidates for this purpose. Most of their contents are water, and it is also possible to prepare them on a large scale.

\section{Conclusions}

According to existing studies and available sciences, polymeric nanoparticles are more suitable for larvicides, lipid nanocarriers are more suitable for repellents, and nanoemulsions 
are more suitable for adulticide. Moreover, some recommendations worth to be mentioned: a) performing bioassay tests under field conditions, b) test of side effects of EO-based nanoformulations on non-target organisms, c) determination of the insecticidal effect of EObased nanoformulations against other medically important vectors, d) attempt to the application of EO-based nanoformulations in the vector control industry.

\section{Funding}

NIMAD Institute (Iranian National Institute for Medical Research Development) supported this research, grant No. 983942.

\section{Acknowledgments}

This research has no acknowledgment.

\section{Conflicts of Interest}

The authors declare no conflict of interest.

\section{References}

1. Sanei-Dehkordi, A.; Gholami, S.; Abai, M.R.; Sedaghat, M.M. Essential oil composition and larvicidal evaluation of Platycladus orientalis against two mosquito vectors, Anopheles stephensi and Culex pipiens. J. Arthropod. Borne. Dis. 2018, 12, 101-107, https://doi.org/10.18502/jad.v12i2.35.

2. Rose, R.I. Pesticides and public health: integrated methods of mosquito management. Emerg. Infect. Dis. 2001, 7, 17-23, https://doi.org/10.3201/eid0701.010103.

3. Sanei-Dehkordi, A.; Sedaghat, M.M.; Vatandoost, H.; Abai, M.R. Chemical Compositions of the Peel Essential Oil of Citrus aurantium and its Natural Larvicidal Activity against the Malaria Vector Anopheles stephensi (Diptera: Culicidae) in Comparison with Citrus paradisi. J. Arthropod. Borne. Dis. 2016, 10, 577585.

4. Tolle, M.A. Mosquito-borne Diseases. Curr. Probl. Pediatr. Adolesc. Health Care 2009, 39, 97-140, https://doi.org/10.1016/j.cppeds.2009.01.001.

5. Sanei-Dehkordi, A.; Soleimani-Ahmadi, M.; Salim Abadi, Y.; Paksa, A. Wild chive oil is an extremely effective larvicide against malaria mosquito vector Anopheles stephensi. Asian Pac. J. Trop. Med. 2019, 12, 170-174, https://doi.org/10.4103/1995-7645.257117.

6. Kurtovic, L.; Boyle, M.J.; Opi, D.H.; Kennedy, A.T.; Tham, W.H.; Reiling, L.; Chan, J.A.; Beeson, J.G. Complement in malaria immunity and vaccines. Immunol. Rev. 2020, 293, 38-56, https://doi.org/10.1111/imr.12802.

7. Wilder-Smith, A.; Ooi, E.-E.; Horstick, O.; Wills, B. Dengue. The Lancet 2019, 393, 350-363, https://doi.org/10.1016/S0140-6736(18)32560-1.

8. Osanloo, M.; Sedaghat, M.M.; Sanei-Dehkordi, A.; Amani, A. Plant-Derived Essential Oils; Their Larvicidal Properties and Potential Application for Control of Mosquito-Borne Diseases. Galen. Medical. J. 2019, 8, https://doi.org/10.31661/gmj.v8i0.1532.

9. Duarte, J.L.; Maciel de Faria Motta Oliveira, A.E.; Pinto, M.C.; Chorilli, M. Botanical insecticide-based nanosystems for the control of Aedes (Stegomyia) aegypti larvae. Environ. Sci. Pollut. Res. 2020, 27, 2873728748, https://doi.org/10.1007/s11356-020-09278-y.

10. Sanei-Dehkordi, A.; Soleimani-Ahmadi, M.; Akbarzadeh, K.; Salim Abadi, Y.; Paksa, A.; Gorouhi, M.A.; Mohammadi-Azni, S. Chemical composition and mosquito larvicidal properties of essential oil from leaves of an Iranian indigenous plant Zhumeria majdae. J. Essent. Oil-Bear. Plants. 2016, 19, 1454-1461, https://doi.org/10.1080/0972060x.2016.1222886.

11. Hemingway, J.; Beaty, B.J.; Rowland, M.; Scott, T.W.; Sharp, B.L. The Innovative Vector Control Consortium: improved control of mosquito-borne diseases. Trends. Parasitol. 2006, 22, 308-312, https://doi.org/10.1016/j.pt.2006.05.003.

12. Pates, H.; Curtis, C. Mosquito behavior and vector control. Annu. Rev. Entomol. 2005, 50, 53-70, https://doi.org/10.1146/annurev.ento.50.071803.130439.

13. Sanei-Dehkordi, A.; Vatandoost, H.; Abaei, M.R.; Davari, B.; Sedaghat, M.M. Chemical composition and larvicidal activity of Bunium persicum essential oil against two important mosquitoes vectors. J. Essent. OilBear. Plants. 2016, 19, 349-357, https://doi.org/10.1080/0972060x.2015.1137240. 
14. Sedaghat, M.M.; Dehkordi, A.S.; Abaie, M.R.; Khanavi, M.; Mohtarami, F.; Saim Abadi, Y.; Rafi, F.; Vatandoost, H. Larvicidal Activity of Essential Oils of Apiaceae Plants against Malaria Vector. Anopheles stephensi. Iran J. Arthropod-Borne Dis 2011, 5, 51-59.

15. Chang, X.; Zhong, D.; Fang, Q.; Hartsel, J.; Zhou, G.; Shi, L.; Fang, F.; Zhu, C.; Yan, G. Multiple resistances and complex mechanisms of Anopheles sinensis mosquito: a major obstacle to mosquito-borne diseases control and elimination in China. PLoS Negl. Trop. Dis. 2014, 8, https://doi.org/10.1371/journal.pntd.0002889.

16. Islam, J.; Zaman, K.; Duarah, S.; Raju, P.S.; Chattopadhyay, P. Mosquito repellents: An insight into the chronological perspectives and novel discoveries. Acta Trop. 2017, 167-230, 216-230, https://doi.org/10.1016/j.actatropica.2016.12.031.

17. Roy, D.N.; Goswami, R.; Pal, A. The insect repellents: A silent environmental chemical toxicant to the health. Environ. Toxicol. Pharmacol. 2017, 50, 91-102, https://doi.org/10.1016/j.etap.2017.01.019.

18. Mozaffari, E.; Abai, M.R.; Khanavi, M.; Vatandoost, H.; Sedaghat, M.M.; Moridnia, A.; Saber-Navaei, M.; Sanei-Dehkordi, A.; Rafi, F. Chemical composition, larvicidal and repellency properties of Cionura erecta (L.) Griseb. against malaria vector, Anopheles stephensi Liston (Diptera: Culicidae). J. Arthropod. Borne. Dis. 2014, 8, 147-155.

19. Osanloo, M.; Amani, A.; Sereshti, H.; Shayeghi, M.; Sedaghat, M.M. Extraction and chemical composition essential oil of Kelussia odoratissima and comparison its larvicidal activity with Z-ligustilide (major constituent) against Anopheles stephensi. J. Entomol. Zool. Stud. 2017, 5, 611-616.

20. Vatandoost, H.; Sanei Dehkordi, A.; Sadeghi, S.M.T.; Davari, B.; Karimian, F.; Abai, M.R.; Sedaghat, M.M. Identification of chemical constituents and larvicidal activity of Kelussia odoratissima Mozaffarian essential oil against two mosquito vectors Anopheles stephensi and Culex pipiens (Diptera: Culicidae). Exp. Parasitol. 2012, 132, 470-474, https://doi.org/10.1016/j.exppara.2012.09.010.

21. Sedaghat, M.M.; Dehkordi, A.S.; Khanavi, M.; Abai, M.R.; Mohtarami, F.; Vatandoost, H. Chemical composition and larvicidal activity of essential oil of Cupressus arizonica E.L. Greene against malaria vector Anopheles stephensi Liston (Diptera: Culicidae). Pharmacognosy Res. 2011, 2, 135-139.

22. Osanloo, M.; Ghaznavi, G.; Abdollahi, A. Sureveying the chemical composition and antibacterial activity of essential oils from selected medicinal plants against human pathogens. Iran. J. Microbiol. 2020, 12, 505512, https://doi.org/10.18502/ijm.v12i6.5032.

23. Noorpisheh Ghadimi, S.; Sharifi, N.; Osanloo, M. The leishmanicidal activity of essential oils: A systematic review. Journal of Herbmed Pharmacology 2020, 9, 300-308, https://doi.org/10.34172/jhp.2020.38.

24. Moemenbellah-Fard, M.D.; Abdollahi, A.; Ghanbariasad, A.; Osanloo, M. Antibacterial and leishmanicidal activities of Syzygium aromaticum essential oil versus its major ingredient, eugenol. Flavour. Fragr. J. 2020, 9, 1-7, https://doi.org/10.1002/ffj.3595.

25. Osanloo, M.; Sedaghat, M.M.; Esmaeili, F.; Amani, A. Larvicidal Activity of Essential Oil of Syzygium aromaticum (Clove) in Comparison with Its Major Constituent, Eugenol, against Anopheles stephensi. $J$. Arthropod. Borne. Dis. 2018, 12, 361-369, https://doi.org/10.18502/jad.v12i4.354.

26. Soleimani-Ahmadi, M.; Abtahi, S.M.; Madani, A.; Paksa, A.; Abadi, Y.S.; Gorouhi, M.A.; Sanei-Dehkordi, A. Phytochemical profile and mosquito larvicidal activity of the essential oil from aerial parts of Satureja bachtiarica Bunge against malaria and lymphatic filariasis vectors. J. Essent. Oil-Bear. Plants. 2017, 20, 328-336, https://doi.org/10.1080/0972060x.2017.1305919.

27. Pirmohammadi, M.; Shayeghi, M.; Vatandoost, H.; Abaei, M.R.; Mohammadi, A.; Bagheri, A.; Khoobdel, M.; Bakhshi, H.; Pirmohammadi, M.; Tavassoli, M. Chemical composition and repellent activity of Achillea vermiculata and Satureja hortensis against Anopheles stephensi. J. Arthropod. Borne. Dis. 2016, 10, 201210 .

28. Moemenbellah-Fard, M.D.; Shahriari-Namadi, M.; Kelidari, H.R.; Nejad, Z.B.; Ghasemi, H.; Osanloo, M. Chemical composition and repellent activity of nine medicinal essential oils against Anopheles stephensi, the main malaria vector. International Journal of Tropical Insect Science 2020, https://doi.org/10.1007/s42690-020-00325-2.

29. Soleimani-Ahmadi, M.; Sanei-Dehkordi, A.; Turki, H.; Madani, A.; Abadi, Y.S.; Paksa, A.; Gorouhi, M.A.; Rashid, G. Phytochemical properties and insecticidal potential of volatile oils from Tanacetum persicum and Achillea kellalensis against two medically important mosquitoes. J. Essent. Oil-Bear. Plants. 2017, 20, 1254-1265, https://doi.org/10.1080/0972060x.2017.1388752.

30. Soleimani-Ahmadi, M.; Gorouhi, M.A.; Azani, S.; Abadi, Y.S.; Paksa, A.; Rashid, G.; Sanei-Dehkordi, A. Larvicidial Effects of essential oil and methanol extract of Achillea wilhelmsii C. Koch (Asteraceae) against Anopheles stephensi Liston (Diptera: Culicidae), a malaria vector. J. Kerman. Univ. Med. Sci. 2017, 24, 5867.

31. Sedaghat, M.M.; Dehkordi, A.S.; Khanavi, M.; Abai, M.R.; Hadjiakhoondi, A.; Mohtarami, F.; Vatandoost, H. Phytochemistry and larvicidal activity of Eucalyptus camaldulensis against malaria vector, Anopheles stephensi. Asian Pac. J. Trop. Med. 2010, 3, 841-845, https://doi.org/10.1016/S1995-7645(10)60203-9.

32. Khanavi, M.; Vatandoost, H.; Dehaghi, N.K.; Dehkordi, A.S.; Sedaghat, M.M.; Hadjiakhoondi, A.; Hadjiakhoondi, F. Larvicidal activities of some Iranian native plants against the main malaria vector, Anopheles stephensi. Acta Med. Iran. 2013, 51, 141-147. 
33. Osanloo, M.; Arish, J.; Sereshti, H. Developed methods for the preparation of electrospun nanofibers containing plant-derived oil or essential oil: a systematic review. Polym. Bull. 2019, 77, 6085-6104, https://doi.org/10.1007/s00289-019-03042-0.

34. Shirkhanloo, H.; Osanloo, M.; Ghazaghi, M.; Hassani, H. Validation of a new and cost-effective method for mercury vapor removal based on silver nanoparticles coating on micro glassy balls. Atmos. Pollut. Res. 2017, 8, 359-365, https://doi.org/10.1016/j.apr.2016.10.004.

35. Osanloo, M.; Abdollahi, A.; Valizadeh, A.; Abedinpour, N. Antibacterial potential of essential oils of Zataria multiflora and Mentha piperita, micro- and nano-formulated forms. Iran. J. Microbiol. 2020, 12, 43-51, https://doi.org/10.18502/ijm.v12i1.2517.

36. Abdollahi, A.; Zarenezhad, E.; Osanloo, M.; Ghaznavi, G.; Khalili Pour, M. Promising antibacterial activity of a mat of polycaprolactone nanofibers impregnated with a green nanogel. Nanomed. Res. J. 2020, 5, 192201, https://doi.org/10.22034/NMRJ.2020.02.010.

37. Pitorre, M.; Gondé, H.; Haury, C.; Messous, M.; Poilane, J.; Boudaud, D.; Kanber, E.; Rossemond Ndombina, G.A.; Benoit, J.P.; Bastiat, G. Recent advances in nanocarrier-loaded gels: Which drug delivery technologies against which diseases? J. Control. Release 2017, 266, 140-155, https://doi.org/10.1016/j.jconrel.2017.09.031.

38. Rizvi, S.A.A.; Saleh, A.M. Applications of nanoparticle systems in drug delivery technology. Saudi Pharm J 2018, 26, 64-70, https://doi.org/10.1016/j.jsps.2017.10.012.

39. Echeverría, J.; Albuquerque, R.D.D.G.D. Nanoemulsions of essential oils: New tool for control of vectorBorne diseases and in vitro effects on some parasitic agents. Medicines 2019, 6, https://doi.org/10.3390/medicines6020042.

40. Pavoni, L.; Perinelli, D.R.; Bonacucina, G.; Cespi, M.; Palmieri, G.F. An Overview of Micro-and Nanoemulsions as Vehicles for Essential Oils: Formulation, Preparation and Stability. Nanomaterials 2020, 10, https://doi.org/10.3390/nano10010135.

41. Singh, Y.; Meher, J.G.; Raval, K.; Khan, F.A.; Chaurasia, M.; Jain, N.K.; Chourasia, M.K. Nanoemulsion: Concepts, development and applications in drug delivery. J. Control. Release 2017, 252, 28-49, https://doi.org/10.1016/j.jconrel.2017.03.008.

42. Palazzolo, S.; Bayda, S.; Hadla, M.; Caligiuri, I.; Corona, G.; Toffoli, G.; Rizzolio, F. The Clinical Translation of Organic Nanomaterials for Cancer Therapy: A Focus on Polymeric Nanoparticles, Micelles, Liposomes and Exosomes. Curr. Med. Chem. 2018, 25, 4224-4268, https://doi.org/10.2174/0929867324666170830113755.

43. Esmaeili, F.; Rajabnejhad, S.; Partoazar, A.R.; Mehr, S.E.; Faridi-Majidi, R.; Sahebgharani, M.; Syedmoradi, L.; Rajabnejhad, M.R.; Amani, A. Anti-inflammatory effects of eugenol nanoemulsion as a topical delivery system. Pharm. Dev. Technol. 2016, 21, 887-893, https://doi.org/10.3109/10837450.2015.1078353.

44. Crucho, C.I.C.; Barros, M.T. Polymeric nanoparticles: A study on the preparation variables and characterization methods. Mater. Sci. Eng. C Mater. Biol. Appl. 2017, 80, 771-784, https://doi.org/10.1016/j.msec.2017.06.004.

45. Valizadeh, A.; Shirzad, M.; Pourmand, M.R.; Farahmandfar, M.; Sereshti, H.; Amani, A. Levofloxacin nanoemulsion gel has a powerful healing effect on infected wound in streptozotocin-induced diabetic rats. Drug Deliv Transl Res 2020, https://doi.org/10.1007/s13346-020-00794-5.

46. Azami, S.J.; Teimouri, A.; Keshavarz, H.; Amani, A.; Esmaeili, F.; Hasanpour, H.; Elikaee, S.; Salehiniya, H.; Shojaee, S. Curcumin nanoemulsion as a novel chemical for the treatment of acute and chronic toxoplasmosis in mice. Int J Nanomedicine 2018, 13, 7363-7374, https://doi.org/10.2147/ijn.s181896.

47. Lim, S.B.; Banerjee, A.; Önyüksel, H. Improvement of drug safety by the use of lipid-based nanocarriers. $J$. Control. Release 2012, 163, 34-45, https://doi.org/10.1016/j.jconrel.2012.06.002.

48. Carbone, C.; Leonardi, A.; Cupri, S.; Puglisi, G.; Pignatello, R. Pharmaceutical and biomedical applications of lipid-based nanocarriers. Pharm Pat Anal 2014, 3, 199-215, https://doi.org/10.4155/ppa.13.79.

49. Mishra, D.K.; Shandilya, R.; Mishra, P.K. Lipid based nanocarriers: a translational perspective. Nanomedicine 2018, 14, 2023-2050, https://doi.org/10.1016/j.nano.2018.05.021.

50. Trucillo, P.; Ferrari, P.; Campardelli, R.; Reverchon, E.; Perego, P. A Supercritical Assisted Process for the Production of Amoxicillin Loaded Liposomes for Anti-microbial Applications. J. Supercrit. Fluids. 2020, 163, https://doi.org/10.1016/j.supflu.2020.104842.

51. Zahin, N.; Anwar, R.; Tewari, D.; Kabir, M.T.; Sajid, A.; Mathew, B.; Uddin, M.S. Nanoparticles and its biomedical applications in health and diseases: special focus on drug delivery. Environ. Sci. Pollut. Res. 2020, 27, 19151-19168, https://doi.org/10.1007/s11356-019-05211-0.

52. Bulbake, U.; Doppalapudi, S.; Kommineni, N.; Khan, W. Liposomal Formulations in Clinical Use: An Updated Review. Pharmaceutics 2017, 9, https://doi.org/10.3390/pharmaceutics9020012.

53. Osanloo, M.; Assadpour, S.; Mehravaran, A.; Abastabar, M.; Akhtari, J. Niosome-loaded antifungal drugs as an effective nanocarrier system: A mini review. Curr. Med. Mycol 2018, 4, 31-36, https://doi.org/10.18502/cmm.4.4.384.

54. Souto, E.B.; Baldim, I.; Oliveira, W.P.; Rao, R.; Yadav, N.; Gama, F.M.; Mahant, S. SLN and NLC for topical, dermal, and transdermal drug delivery. Expert Opin Drug Deliv 2020, 17, 357-377, https://doi.org/10.1080/17425247.2020.1727883. 
55. Esmaeili, M.; Aghajani, M.; Abbasalipourkabir, R.; Amani, A. Budesonide-loaded solid lipid nanoparticles for pulmonary delivery: preparation, optimization, and aerodynamic behavior. Artif Cells Nanomed Biotechnol 2016, 44, 1964-1971, https://doi.org/10.3109/21691401.2015.1129614.

56. Ban, C.; Jo, M.; Park, Y.H.; Kim, J.H.; Han, J.Y.; Lee, K.W.; Kweon, D.H.; Choi, Y.J. Enhancing the oral bioavailability of curcumin using solid lipid nanoparticles. Food Chem. 2020, 302, https://doi.org/10.1016/j.foodchem.2019.125328.

57. Yuan, Q.; Han, J.; Cong, W.; Ge, Y.; Ma, D.; Dai, Z.; Li, Y.; Bi, X. Docetaxel-loaded solid lipid nanoparticles suppress breast cancer cells growth with reduced myelosuppression toxicity. Int J Nanomedicine 2014, 9, 4829-4846, https://doi.org/10.2147/ijn.s70919.

58. Zhao, Y.; Chang, Y.X.; Hu, X.; Liu, C.Y.; Quan, L.H.; Liao, Y.H. Solid lipid nanoparticles for sustained pulmonary delivery of Yuxingcao essential oil: Preparation, characterization and in vivo evaluation. Int. J. Pharm. 2017, 516, 364-371, https://doi.org/10.1016/j.ijpharm.2016.11.046.

59. Müller, R.H.; Radtke, M.; Wissing, S.A. Solid lipid nanoparticles (SLN) and nanostructured lipid carriers (NLC) in cosmetic and dermatological preparations. Adv Drug Deliv Rev 2002, 54, S131-S155, https://doi.org/10.1016/s0169-409x(02)00118-7.

60. Beloqui, A.; Solinís, M.; Rodríguez-Gascón, A.; Almeida, A.J.; Préat, V. Nanostructured lipid carriers: Promising drug delivery systems for future clinics. Nanomedicine 2016, 12, 143-161, https://doi.org/10.1016/j.nano.2015.09.004.

61. Sur, S.; Rathore, A.; Dave, V.; Reddy, K.R.; Chouhan, R.S.; Sadhu, V. Recent developments in functionalized polymer nanoparticles for efficient drug delivery system. Nano-Structures \& Nano-Objects 2019, 20, https://doi.org/10.1016/j.nanoso.2019.100397.

62. Denton, A.R. Crowding in polymer-nanoparticle mixtures. Int. Rev. Cell Mol. Biol. 2014, 307, 27-71, https://doi.org/10.1016/b978-0-12-800046-5.00003-5.

63. Ferrari, R.; Sponchioni, M. Polymer nanoparticles for the intravenous delivery of anticancer drugs: the checkpoints on the road from the synthesis to clinical translation. Nanoscale 2018, 10, 22701-22719, https://doi.org/10.1039/c8nr05933k.

64. Abyadeh, M.; Sadroddiny, E.; Ebrahimi, A.; Esmaeili, F.; Landi, F.S.; Amani, A. Electrosprayed chitosan nanoparticles: facile and efficient approach for bacterial transformation. Int. Nano Lett. 2017, 7, 291-295, https://doi.org/10.1007/s40089-017-0224-0.

65. Hu, J.; Sheng, Y.; Shi, J.; Yu, B.; Yu, Z.; Liao, G. Long Circulating Polymeric Nanoparticles for Gene/Drug Delivery. Curr Drug Metab 2018, 19, 723-738, https://doi.org/10.2174/1389200219666171207120643.

66. Teimouri, A.; Azami, S.J.; Keshavarz, H.; Esmaeili, F.; Alimi, R.; Mavi, S.A.; Shojaee, S. Anti-Toxoplasma activity of various molecular weights and concentrations of chitosan nanoparticles on tachyzoites of RH strain. Int J Nanomedicine 2018, 13, 1341-1351, https://doi.org/10.2147/ijn.s158736.

67. Adebileje, T.; Valizadeh, A.; Amani, A. Effect of formulation parameters on the size of PLGA nanoparticles encapsulating bovine serum albumin: a response surface methodology. J. contemp. med. sci 2017, 3, 306312, https://doi.org/10.22317/jcms.12201704.

68. George, A.; Shah, P.A.; Shrivastav, P.S. Natural biodegradable polymers based nanoformulations for drug delivery: A review. Int. J. Pharm. 2019, 561, 244-264, https://doi.org/10.1016/j.ijpharm.2019.03.011.

69. Sebaaly, C.; Jraij, A.; Fessi, H.; Charcosset, C.; Greige-Gerges, H. Preparation and characterization of clove essential oil-loaded liposomes. Food Chem. 2015, 178, 52-62, https://doi.org/10.1016/j.foodchem.2015.01.067.

70. Ghosh, V.; Mukherjee, A.; Chandrasekaran, N. Optimization of process parameters to formulate Nanoemulsion by spontaneous emulsification: Evaluation of Larvicidal activity against Culex quinquefasciatus Larva. BioNanoScience 2014, 4, 157-165, https://doi.org/10.1007/s12668-014-0131-z.

71. Anjali, C.; Sharma, Y.; Mukherjee, A.; Chandrasekaran, N. Neem oil (Azadirachta indica) nanoemulsiona potent larvicidal agent against Culex quinquefasciatus. Pest Manag. Sci. 2012, 68, 158-163.

72. Oliveira, A.E.; Duarte, J.L.; Amado, J.R.; Cruz, R.A.; Rocha, C.F.; Souto, R.N.; Ferreira, R.M.; Santos, K.; da Conceicao, E.C.; de Oliveira, L.A., et al. Development of a Larvicidal Nanoemulsion with Pterodon emarginatus Vogel Oil. PLoS One 2016, 11, https://doi.org/10.1371/journal.pone.0145835.

73. Ferreira, R.M.; Duarte, J.L.; Cruz, R.A.; Oliveira, A.E.; Araújo, R.S.; Carvalho, J.C.; Mourão, R.H.; Souto, R.N.; Fernandes, C.P. A herbal oil in water nano-emulsion prepared through an ecofriendly approach affects two tropical disease vectors. Rev. Bras. Farmacogn. 2019, 29, 778-784, https://doi.org/10.1016/j.bjp.2019.05.003.

74. Osanloo, M.; Sereshti, H.; Sedaghat, M.M.; Amani, A. Nanoemulsion of Dill essential oil as a green and potent larvicide against Anopheles stephensi. Environ. Sci. Pollut. Res. 2018, 25, 6466-6473, https://doi.org/10.1007/s11356-017-0822-4.

75. Osanloo, M.; Amani, A.; Sereshti, H.; Abai, M.R.; Esmaeili, F.; Sedaghat, M.M. Preparation and optimization nanoemulsion of Tarragon (Artemisia dracunculus) essential oil as effective herbal larvicide against Anopheles stephensi. Ind. Crops. Prod. 2017, 109, 214-219, https://doi.org/10.1016/j.indcrop.2017.08.037. 
76. Sugumar, S.; Clarke, S.; Nirmala, M.; Tyagi, B.; Mukherjee, A.; Chandrasekaran, N. Nanoemulsion of eucalyptus oil and its larvicidal activity against Culex quinquefasciatus. Bull. Entomol. Res. 2014, 104, 393402, https://doi.org/10.1017/s000748531400008x.

77. Osanloo, M.; Sedaghat, M.M.; Sereshti, H.; Amani, A. Nano-encapsulated tarragon (Artemisia dracunculus) essential oil as a sustained release nano-larvicide. J. contemp. med. sci 2019, 5, 82-89.

78. Osanloo, M.; Sedaghat, M.M.; Sereshti, H.; Rahmani, M.; Saeedi Landi, F.; Amani, A. Chitosan nanocapsules of tarragon essential oil with low cytotoxicity and long-lasting activity as a green nanolarvicide. J. Nanostruct. 2019, 9, 723-735.

79. Tampucci, S.; Burgalassi, S.; Chetoni, P.; Monti, D. Cutaneous permeation and penetration of sunscreens: formulation strategies and in vitro methods. Cosmetics 2018, 5, 1-17, https://doi.org/10.3390/cosmetics5010001.

80. Monti, D.; Chetoni, P.; Burgalassi, S.; Tampucci, S.; Centini, M.; Anselmi, C. 4-Methylbenzylidene camphor microspheres: reconstituted epidermis (Skinethic ${ }^{\circledR}$ ) permeation and distribution. Int. J. Cosmet. Sci. 2015, 37, 298-305.

81. Siddiqi, K.S.; Husen, A.; Rao, R.A. A review on biosynthesis of silver nanoparticles and their biocidal properties. J. Nanobiotechnology. 2018, 16, https://doi.org/10.1186/s12951-018-0334-5.

82. Amini, S.M. Preparation of antimicrobial metallic nanoparticles with bioactive compounds. Mater. Sci. Eng. C 2019, 103, https://doi.org/10.1016/j.msec.2019.109809.

83. Amini, S.M.; Akbari, A. Metal nanoparticles synthesis through natural phenolic acids. IET nanobiotechnology 2019, 13, 771-777, https://doi.org/10.1049/iet-nbt.2018.5386.

84. Amiri, S.; Yousefi-Ahmadipour, A.; Hosseini, M.-J.; Haj-Mirzaian, A.; Momeny, M.; Hosseini-Chegeni, H.; Mokhtari, T.; Kharrazi, S.; Hassanzadeh, G.; Amini, S.M.; Jafarinejad, S.; Ghazi-Khansari, M. Maternal exposure to silver nanoparticles are associated with behavioral abnormalities in adulthood: Role of mitochondria and innate immunity in developmental toxicity. Neurotoxicology 2018, 66, 66-77, https://doi.org/10.1016/j.neuro.2018.03.006.

85. Oh, Y.; Chun, K.-Y.; Lee, E.; Kim, Y.-J.; Baik, S. Functionalized nano-silver particles assembled on onedimensional nanotube scaffolds for ultra-highly conductive silver/polymer composites. J. Mater. Chem. 2010, 20, 3579-3582, https://doi.org/10.1039/c0jm00086h.

86. Arjunan, N.K.; Murugan, K.; Rejeeth, C.; Madhiyazhagan, P.; Barnard, D.R. Green synthesis of silver nanoparticles for the control of mosquito vectors of malaria, filariasis, and dengue. Vector. Borne. Zoonotic. Dis. 2012, 12, 262-268, https://doi.org/10.1089/vbz.2011.0661.

87. Subarani, S.; Sabhanayakam, S.; Kamaraj, C. Studies on the impact of biosynthesized silver nanoparticles (AgNPs) in relation to malaria and filariasis vector control against Anopheles stephensi Liston and Culex quinquefasciatus Say (Diptera: Culicidae). Parasitol. Res. 2013, 112, 487-499, https://doi.org/10.1007/s00436-012-3158-5.

88. Osanloo, M.; Amini, S.M.; Sedaghat, M.M.; Amani, A. Larvicidal activity of chemically synthesized silver nanoparticles against Anopheles stephensi. J. Pharm. Negat. Results. 2019, 10, 69-72.

89. M Azmy, R.; E El Gohary, E.G.; M Mahmoud, D.; AM Salem, D.; A Abdou, M.; S Salama, M. Assessment of larvicidal activity of nanoemulsion from Citrus sinensis essential oil on Culex pipiens L.(Diptera: Culicidae). Egyptian Journal of Aquatic Biology and Fisheries 2019, 23, 61-67, https://doi.org/10.21608/ejabf.2019.35100.

90. Jesser, E.N.; Yeguerman, C.O.; Gili, V.O.; Santillan, G.O.; Murray, A.P.; Domini, C.; Werdin González, J.O. Optimization and characterization of essential oil nanoemulsions using ultrasound for new ecofriendly insecticides. ACS. Sustain. Chem. Eng. 2020, 8, 7981-7992, https://doi.org/10.1021/acssuschemeng.0c02224.

91. Amado, J.R.R.; Prada, A.L.; Diaz, J.G.; Souto, R.N.P.; Arranz, J.C.E.; de Souza, T.P. Development, larvicide activity, and toxicity in non-target species of the Croton linearis Jacq essential oil nanoemulsion. Environ. Sci. Pollut. Res. 2020, 27, 9410-9423, https://doi.org/10.1007/s11356-020-07608-8.

92. Kala, S.; Sogan, N.; Verma, P.; Naik, S.; Agarwal, A.; Patanjali, P.; Kumar, J. Nanoemulsion of cashew nut shell liquid bio-waste: Mosquito larvicidal activity and insights on possible mode of action. S. Afr. J. Bot. 2019, 127, 293-300, https://doi.org/10.1016/j.sajb.2019.10.006.

93. Ferreira, R.; D'Haveloose N, P.; Cruz, R.A.S.; Araujo, R.S.; Carvalho, J.C.T.; Rocha, L.; Fernandes, L.P.; Da Costa, T.S.; Fernandes, C.P.; Souto, R.N.P. Nano-emulsification Enhances the Larvicidal Potential of the Essential Oil of Siparuna guianensis (Laurales: Siparunaceae) Against Aedes (Stegomyia) aegypti (Diptera: Culicidae). J. Med. Entomol. 2020, 57, 788-796, https://doi.org/10.1093/jme/tjz221.

94. Sogan, N.; Kapoor, N.; Kala, S.; Patanjali, P.; Nagpal, B.; Kumar, V.; Valecha, N. Larvicidal activity of castor oil Nanoemulsion against malaria vector Anopheles culicifacies. Int. J. Mosq. Res. 2018, 5, 01-06.

95. Nazeer, A.A.; Rajan, H.V.; Vijaykumar, S.D.; Saravanan, M. Evaluation of Larvicidal and Repellent Activity of Nanocrystal Emulsion Synthesized from F. glomerata and Neem Oil Against Mosquitoes. $J$. Clust. Sci. 2019, 30, 1649-1661, https://doi.org/10.1007/s10876-019-01611-x.

96. Essa, E.; Mo'men, S.A.; Rady, M.H.; Ma'moun, S.A.; Barakat, E.M.; Salama, M.S. Eucalyptus oil nanoemulsion encapsulated in chitosan beads as a new approach in control of Culex pipiens larvae. Int. J. Mosq. Res. 2019, 6, 63-69. 
97. Norris, E.J.; Coats, J.R. Current and future repellent technologies: the potential of spatial repellents and their place in mosquito-borne disease control. Int. J. Environ. Res. Public Health 2017, 14, 124, https://doi.org/10.3390/ijerph14020124.

98. Sanghong, R.; Junkum, A.; Chaithong, U.; Jitpakdi, A.; Riyong, D.; Tuetun, B.; Champakaew, D.; Intirach, J.; Muangmoon, R.; Chansang, A. Remarkable repellency of Ligusticum sinense (Umbelliferae), a herbal alternative against laboratory populations of Anopheles minimus and Aedes aegypti (Diptera: Culicidae). Malar. J. 2015, 14, 307, https://doi.org/10.1186/s12936-015-0816-y.

99. Koren, G.; Matsui, D.; Bailey, B. DEET-based insect repellents: safety implications for children and pregnant and lactating women. CMAJ 2003, 169, 209-212.

100. Anitha, R.; Ramachandran, T.; Rajendran, R.; Mahalakshmi, M. Microencapsulation of lemon grass oil for mosquito repellent finishes in polyester textiles. Elixir Bio Phys 2011, 40, 5196-5200.

101. Sakulku, U.; Nuchuchua, O.; Uawongyart, N.; Puttipipatkhachorn, S.; Soottitantawat, A.; Ruktanonchai, U. Characterization and mosquito repellent activity of citronella oil nanoemulsion. Int. J. Pharm. 2009, 372, 105-111, https://doi.org/10.1016/j.ijpharm.2008.12.029.

102. Nuchuchua, O.; Sakulku, U.; Uawongyart, N.; Puttipipatkhachorn, S.; Soottitantawat, A.; Ruktanonchai, U. In vitro characterization and mosquito (Aedes aegypti) repellent activity of essential-oils-loaded nanoemulsions. AAPS PharmSciTech 2009, 10, https://doi.org/10.1208/s12249-009-9323-1.

103. de Souza, M.; da Silva, L.; Macêdo, M.; Lacerda-Neto, L.; dos Santos, M.; Coutinho, H.; Cunha, F. Adulticide and repellent activity of essential oils against Aedes aegypti (Diptera: Culicidae)-A review. $S$. Afr. J. Bot. 2019, 124, 160-165, https://doi.org/10.1016/j.sajb.2019.05.007.

104. Navayan, A.; Moghimipour, E.; Khodayar, M.J.; Vazirianzadeh, B.; Siahpoosh, A.; Valizadeh, M.; Mansourzadeh, Z. Evaluation of the Mosquito Repellent Activity of Nano-sized Microemulsion of Eucalyptus globulus Essential Oil Against Culicinae. Jundishapur J. Nat. Pharm. Prod 2017, 12, https://doi.org/10.5812/jjnpp.55626.

105. Mohammadi, R.; Khoobdel, M.; Negahban, M.; Khani, S. Nanoemulsified Mentha piperita and Eucalyptus globulus oils exhibit enhanced repellent activities against Anopheles stephensi. Asian Pac. J. Trop. Med. 2019, 12, 520-527, https://doi.org/10.4103/1995-7645.271292.

106. Elias, P.M. Stratum corneum defensive functions: an integrated view. J. Invest. Dermatol. 2005, 125, 183200, https://doi.org/10.1111/j.0022-202X.2005.23668.x.

107. Ramar, M.; Manonmani, P.; Arumugam, P.; Kannam, S.; Erusan, R.; Baskaran, N.; Murugan, K. Nanoinsecticidal formulations from essential oil (Ocimum sanctum) and fabricated in filter paper on adult of Aedes aegypti and Culex quinquefasciatus. J. Entomol. Zool. Stud 2017, 5, 1769-1774. 